\title{
Influencia del diámetro y color de plantillas reductoras de la superficie de proyección de los colorímetros en la medida del color de una superficie
}

\section{Effect of the diameter and colour of colorimeter aperture reducing templates on colour coordinate measurements}

\author{
F. Arroyo $^{(*)}$, M. Alcalde ${ }^{(*)}$, R. Villegas ${ }^{(*)}$ y M. D. Robador ${ }^{(*)}$
}

Recepción/Received: 3-VII-06

Aceptación/Accepted: 9-IV-07

Publicado online/Online publishing: 28-V-08

\section{RESUMEN}

En los colorímetros que existen en el mercado, la luz se recoge mediante un tubo de cierto diámetro y los valores de las coordenadas cromáticas que da el medidor son una media de las obtenidas en dicha superficie. Cuando la superficie a medir no tiene un color uniforme, como ocurre en el caso de los materiales pétreos, la medida de color es más representativa cuanto mayor es la apertura del tubo de medida ya que la superficie medida es mayor. Este hecho, que en ocasiones supone una ventaja, presenta el inconveniente de que cuando la superficie objeto de estudio es inferior a la apertura del tubo de proyección del colorímetro utilizado, los valores obtenidos integran zonas no deseadas.

Una posible solución a este inconveniente es la utilización de plantillas que reduzcan el área de medida. En este trabajo se ensayan plantillas adaptadoras del tubo de medida de un colorímetro Minolta CR-210, y se llega a la conclusión de que su uso, además de fácil, permite obtener el color original de la superficie medida, es decir, el valor que tendría si no se hubieran utilizado las plantillas.

Palabras clave: colorimetría, plantillas, coordenadas cromáticas, adaptadores.

\section{SUMMARY}

The colour coordinate values measured with the colorimeters presently on the market are the mean of the readings obtained for the surface area covered by the light projection tube. When the colour of the surface measured is not uniform, such as in the case of stone, the larger the tube aperture the more representative is the colour measurement, for a larger area is involved. While this is often an advantage, when the area studied is smaller than the aperture of the colorimeter used, the values obtained include unwanted information.

One possible way to deal with this drawback is by using templates to reduce the measurement area. Templates adapted to a Minolta CR-210 colorimeter were tested in the present study. The conclusion drawn was that in addition to being convenient to use, they ensured that the readings matched the original colour of the surface, i.e., the value that would have been obtained without the templates.

Keywords: colorimetry, templates, colorimetric coordinates, adapters.

\footnotetext{
(*) Universidad de Sevilla, (Sevilla, España).
} 


\section{INTRODUCCIÓN}

Además del ya muy conocido empleo de la colorimetría en el análisis químico, tanto por emisión como por transmisión, el análisis del color vía reflexión se está extendiendo con gran rapidez, no ya sólo en aplicaciones industriales, como el control de calidad de múltiples materiales (1-5), sino también en las investigaciones científicas. Por ejemplo, el color de una superficie de una piedra es uno de los indicadores de alteración (6). Es una propiedad útil para evaluar tratamientos de conservación $(7,8)$ aplicados a superficies (piedras, metales, etc.), estudios de envejecimiento $(9,10)$, impacto visual (11), o incluso se está utilizando para determinar la cantidad de algunos organismos en superficies de construcción $(12,13)$. También tiene utilización en el campo de la restauración de bienes muebles, especialmente pintura o escultura policromada, permitiendo evaluar el grado de oxidación de barnices o el nivel de limpieza alcanzado $(14,15)$. En el ámbito de la construcción, el color es una de las características elementales a tener en cuenta (16), sobre todo cuando el material se utiliza con fines artísticos y ornamentales.

Una de las principales razones que ha conducido a la utilización del color como medida de una propiedad importante en investigaciones científicas es el hecho de poder objetivar la medida del color. Cada observador puede percibir el color de forma diferente según sea la iluminación, colores adyacentes, ángulo de visión, incluso estado de fatiga, edad, sexo, etc., pero un instrumento de medición del color hace algo que nuestro ojo no puede hacer: asignar un valor objetivo al color que puede ser analizado consistemente en términos de estándares y tolerancias numéricas. Para ello, emite una luz normalizada sobre una superficie y recoge la radiación reflejada por la misma, adaptando esta medida de radiación a unos valores numéricos mediante unos patrones preestablecidos.

Existen varios sistemas de color, como $X Y Z, L * a * b$ y $\mathrm{S}^{*} \mathrm{C} * \mathrm{~h}$ de la Comisión International de I’Eclairage (CIE) o Hunter Lab. En este trabajo se ha utilizado el sistema de color CIEL*a*b* con iluminante estándar D65, recomendado por la $\operatorname{CIE}(17,18)$, en el que cada punto se representa por las coordenadas $L^{*}, a^{*}$ y $b^{*}$, aunque los valores son fácilmente transformados a cualquier otro sistema mediante las adecuadas ecuaciones.

En este sistema, las coordenadas son:

L*: eje vertical que representa la luminosidad, variando desde el negro en la parte inferior, que tiene un valor de cero, al blanco en la parte superior con un valor de 100 .

a*: tendencia al rojo (+) o verde (-). Esta coordenada varía entre -120 y 120.

\section{INTRODUCTION}

In addition to the widely extended use of colorimetry in chemical analysis with both emitted and transmitted light, colour analysis is rapidly spreading to industrial applications such as quality control for many types of materials (1-5) as well as to other areas of scientific research. Surface colour, for instance, is one of the indicators used to detect alteration in stone (6). It is useful for evaluating conservation treatments $(7,8)$ applied to stone, metal and similar surfaces, in ageing $(9,10)$ and visual impact studies (11) and is even being used to determine the density of living organisms on the surfaces of buildings and other structures $(12,13)$. Another area where it is very helpful is in restoration work, particularly to assess the degree of varnish oxidation or depth of cleaning in paintings and polychrome sculptures $(14,15)$. In construction, colour is one of the chief characteristics to be considered (16), particularly in materials used for artistic and ornamental purposes.

One of the main reasons that colour has been used as an important property in scientific research is that can be objectively measured. While individual observers may perceive colour differently depending on the light, adjacent colours, angle of vision and even factors such as fatigue, age, sex and so on, colour measuring instruments do what the human eye cannot: they assign an objective value to colour that can be consistently analyzed and expressed in terms of standards and numerical tolerances. To do so, they emit standardized light on a surface and collect and measure the reflected radiation, adapting the findings to numerical measurements in accordance with pre-established patterns.

Several colour systems are in place, including the Commission internationale de l'Eclairage (CIE) or Hunter Lab XYZ, L*a*b* and $S^{*} C^{*} h^{*}$ schemes. In the CIELAB colour system used in this paper (with the D65 illuminant recommended by the $\operatorname{CIE}(17,18)$, each point is represented by coordinates $L^{*}, a^{*}$ and $b^{*}$, although the values can be readily converted to any other system with the appropriate equations.

The coordinates in this system are:

$\mathbf{L}$ : vertical axis representing lightness, which varies from black at the bottom where the value is zero, to white at the top, where it is 100.

a*: magenta $(+)$ - green (-) scale, with values ranging from -120 to 120 . 
b*: tendencia al azul (-) o amarillo (+). Esta coordenada varía entre -120 y 120.

Los métodos aceptados para la medición de color en muestras opacas consideran superficies homogéneas y uniformes. Las medidas de color en este tipo de superficies es muy sencilla y exacta, basta con seleccionar un punto de medida y utilizar el colorímetro. El valor obtenido de las coordenadas cromáticas reflejará el color de la superficie. Pero en el caso de otros materiales, como es el caso de las piedras sedimentarias o los morteros (compuestos por granos de diversos componentes unidos por un aglomerante), cuanto mayor sea la superficie de medida, más representativos serán los valores que se obtengan, ya que las superficies a medir son heterogéneas y poseen irregularidades.

Por esta razón se ha elegido el colorímetro Minolta (modelo CR-210) que tiene un diámetro del tubo de medida de $53 \mathrm{~mm}$ (uno de los mayores del mercado), mientras que otros modelos existentes tienen un tubo de medida de $8 \mathrm{~mm}$, estando diseñados especialmente para su uso en pintura, cerámica o escultura policromada.

El diámetro del colorímetro puede presentar un inconveniente cuando la superficie a medir es menor que este diámetro, o la forma no es circular, ya que parte de la luz que emite la lámpara no se refleja al escaparse por los huecos que quedan entre el tubo y la superficie reflectante. Los valores así obtenidos no expresan el color verdadero que se está midiendo.

Las probetas de piedra que se utilizan en los ensayos de evaluación de tratamientos son normalmente de forma cúbica y $50 \mathrm{~mm}$ de arista, es decir, sus dimensiones son ligeramente menores que las del tubo del colorímetro. Por ello ha sido necesario utilizar un procedimiento de medida que permitiese emplear el colorímetro con este tipo de probetas, eliminando el problema de la radiación que pasa a través de los huecos que quedan en los bordes de la probeta, radiación que podría falsear las medidas obtenidas.

Para solucionar este problema se han realizado ensayos en los que se reduce este diámetro de medida mediante un accesorio intermedio. Estas pruebas se han dirigido a la elección de una plantilla que interfiera lo menos posible en la medida realizada, ya que en cualquier caso esta adaptación supone la introducción de un color extraño en la superficie.

\section{PARTE EXPERIMENTAL}

\subsection{Materiales}

- Colorímetro Minolta, modelo CR-210, que posee un tubo de proyección de $53 \mathrm{~mm}$ de diámetro. b*: blue (+) - yellow (-) scale, with values ranging from -120 to 120 .

The accepted methods for measuring colour in opaque samples assume even, uniform surfaces. Colour measurements in this type of surfaces are very simple and precise: all it involves is taking the reading with the colorimeter on a selected measuring point. The value of the colour coordinates found defines the colour of the surface. But in other materials such as sedimentary rocks or mortars (whose different granular components are held together by a binder), the larger the measuring surface, the more representative are the values obtained, for the surfaces measured are uneven and irregular.

A Minolta (model CR-210) colorimeter was chosen for its 53- $\mathrm{mm}$ projection tube (one of the largest on the market): other models tend to have an 8-mm tube, specifically designed for use in painting, ceramics or polychrome sculpture.

A large diameter may be a drawback when the surface to be measured is smaller than that size or not circular, however, because part of the light emitted is not reflected, but escapes through the gaps between the projection tube and the reflecting surface. The values obtained under such circumstances do not express the true colour of the surface measured.

The stone specimens used in tests to evaluate treatment effectiveness are normally 50- $\mathrm{mm}$ cubes, i.e., slightly smaller than the colorimeter tube. Consequently, a need was identified for a procedure able to measure this type of specimens with a colorimeter, eliminating the problem of the distortion caused by light from outside the tube coming in through the gaps around the edges of the specimen.

Accessories that reduced the measuring diameter were tested in an attempt to solve this problem. Such tests were geared to finding a template that would interfere as little as possible with the measurement taken, in the realization that any such adaptation entails introducing a colour different from the colour of the surface to be measured.

\section{EXPERIMENTAL}

\subsection{Materials}

- Minolta CR-210 colorimeter with a 53- $\mathrm{mm}$ projection tube. 
- Muestras de superficie cromáticas de referencia. Se han elegido cartulinas comerciales coloreadas de forma homogénea, de forma que el sistema de medida sea sencillo de reproducir.

- Plantillas reductoras del diámetro del tubo de medida del colorímetro Minolta CR-210, fabricadas a partir de cartulinas comerciales. Se han utilizado plantillas de tres colores, coincidiendo con los tres ejes del sistema L*a*b* (negro, rojo y amarillo) y para cada uno de los colores, se han confeccionado plantillas con cuatro diámetros de hueco (20 mm, $30 \mathrm{~mm}, 40 \mathrm{~mm}$ y $45 \mathrm{~mm}$ ).

\subsection{Experimentación y método de trabajo}

La forma del adaptador debe ser lo más parecida posible al área medida por el colorímetro (forma y superficie), por lo que se fabricaron plantillas reductoras con huecos circulares, manteniendo así la forma del tubo del equipo de medida. El diámetro exterior se ajusta al diámetro del tubo de proyección.

Obviamente el uso de una plantilla reductora de este tipo incluye un factor de desviación en la medida, porque se introduce un color diferente al que se quiere medir. Por ejemplo, si la plantilla tiene un hueco con un diámetro de $45 \mathrm{~mm}$, se estaría introduciendo aproximadamente un $28 \%$ de una superficie de un color diferente al original.

Se trata, por tanto, de comprobar si existe alguna dependencia entre las medidas de color reales (toda la superficie de medida del tubo del colorímetro está ocupada por la superficie a medir), y las medidas de color "reducidas", es decir, aquéllas que se han obtenido interponiendo una plantilla reductora entre la superficie a medir y el tubo colorimétrico.

Para ello se ha ensayado con diferentes plantillas reductoras sobre varias superficies cromáticas.

El esquema de trabajo ha sido el siguiente:

1. Caracterización de las plantillas reductoras estudiadas.

Se ha medido el color de las plantillas a utilizar como reductoras para lo que se han realizado tres medidas de color, tomando el valor medio de las mismas. Estos valores pueden verse en la Tabla 1 (el valor de L* es algo elevado debido a la reflectividad de todas las cartulinas comerciales conseguidas). Además, en la Tabla 1 se relacionan los distintos tipos de plantillas utilizados en el ensayo, asignándoles una notación para facilitar la lectura de los resultados.
- Reference colour samples. Uniformly coloured commercial cardboard samples were chosen to devise a readily reproducible measuring system.

- Templates to reduce the diameter of the projection tube on the Minolta CR-210 colorimeter, made from standard coloured cardboard. Twelve templates were made in all: four (with inner diameters of 20,30,40 and $45 \mathrm{~mm}$ ) from each of the three colours that define the $L^{*} a * b *$ system axes (black, magenta and yellow).

\subsection{Experimentation and working method}

Since the shape of the adapter should be as similar as possible to the area measured by the colorimeter (form and size), templates with circular openings were chosen to conform to the shape of the projection tube. The outer diameter was the same as the diameter of the projection tube.

The use of such templates obviously generates measurement deviations, because their colour differs from the colour of the surface to be measured. With templates having a 45-mm inner diameter, for instance, the colour of approximately $28 \%$ of the surface measured differs from the colour of the sample.

The aim, then, was to determine whether any relationship exists between the measurements of the actual colours (when the surface measured covers the entire measuring area of the colorimeter) and the values found for the "reduced aperture" measurements, i.e., the measurements obtained when a template was placed between the surface and the projection tube.

Different templates were therefore tested on surfaces of various colours.

The working procedure was as follows:

\section{Characterization of the templates studied.}

The mean of three colour readings was used for the template values, as shown in Table 1 (the value of $L^{*}$ is somewhat high due to the reflectivity of the commercial samples). Table 1 also gives the different types of templates tested, along with the notation used to facilitate interpretation of the results. 
Tabla 1 / Table 1

Caracterización del color y clasificación de las plantillas reductoras

Characterisationof colour and clasification of the reducing templates

\begin{tabular}{|l|c|c|c|c|c|c|c|}
\cline { 2 - 9 } \multicolumn{1}{c|}{} & \multicolumn{3}{c|}{ Coordenadas cromáticas } & \multicolumn{4}{c|}{ Diámetro / diameter } \\
\hline Plantilla / Template & L* & a* & b* & $\mathbf{2 0} \mathbf{~ m m}$ & $\mathbf{3 0} \mathbf{~} \mathbf{m}$ & $\mathbf{4 0} \mathbf{~} \mathbf{m}$ & $\mathbf{4 5} \mathbf{~ m m}$ \\
\hline Negra / Black & 28.67 & -0.80 & -1.69 & $\mathrm{~N} 20$ & $\mathrm{~N} 30$ & $\mathrm{~N} 40$ & $\mathrm{~N} 45$ \\
\hline Roja / Red & 54.77 & 54.69 & 18.52 & $\mathrm{R} 20$ & $\mathrm{R} 30$ & $\mathrm{R} 40$ & $\mathrm{R} 45$ \\
\hline Amarilla / Yellow & 92.93 & -14.52 & 49.73 & $\mathrm{~A} 20$ & $\mathrm{~A} 30$ & $\mathrm{~A} 40$ & $\mathrm{~A} 45$ \\
\hline
\end{tabular}

2. Elaboración de plantillas reductoras de color rojo, negro y amarillo con diferentes diámetros de hueco. La forma de las plantillas y la disposición de las mismas para medir con el colorímetro pueden verse en la Figura 1.
2. Preparation of the templates (with different inner diameters) from the above three colours. Template shape and positioning for colorimetric readings are shown in Figure 1.

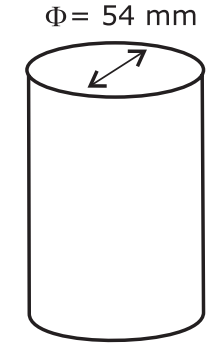

Tubo de proyección Projection tube

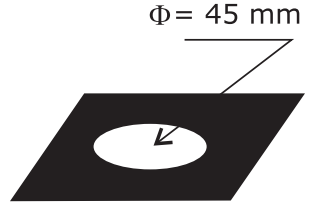

Plantilla reductora Reducing template

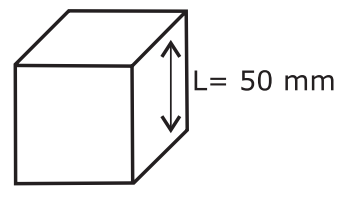

Probeta

Test sample

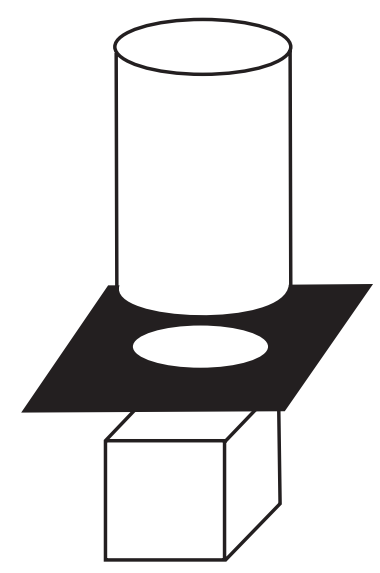

Figura 1. Tubo de proyección, probeta y plantilla reductora. Esquema de la disposición del equipo de medida.

Figure 1. Projection tube, test sample and reducing template. Disposition scheme of the measurement kit.

3. Caracterización del color de las seis superficies coloreadas utilizadas como patrones (se escogieron seis superficies representativas dentro del sólido color). Estos valores se muestran en la Tabla 2.
3. Colour characterization of the six coloured surfaces used as colorimetric patterns (six representative surfaces within each solid colour). The values are given in Table 2.

Tabla 2 / Table 2

Caracterización de las muestras colorimétricas Characterisation of colourimetric samples

\begin{tabular}{|c|c|c|c|c|}
\hline Muestra/ Sample & Color/ Colour & L* & a* & b* \\
\hline $\mathbf{1}$ (M1) & Gris / Grey & 58.65 & 51.55 & 0.44 \\
\hline $\mathbf{2}$ (M2) & Rosa / Pink & 82.11 & 5.45 & 17.42 \\
\hline $\mathbf{3}$ (M3) & Azul intenso / Dark blue & 52.59 & -9.75 & -37.45 \\
\hline $\mathbf{4}$ (M4) & Amarillo / Yellow & 91 & -14.9 & 45.15 \\
\hline $\mathbf{5}$ (M5) & Verde claro / Light green & 84.03 & -12.53 & -1.71 \\
\hline $\mathbf{6}$ (M6) & Verde fuerte / Dark green & 81.8 & -21.88 & 6.18 \\
\hline
\end{tabular}


4. Realización de medidas de color sobre las seis superficies caracterizadas en el apartado 3 utilizando las plantillas reductoras.

\section{RESULTADOS}

Las Tablas 3, 4 y 5 muestran los resultados obtenidos en los ensayos realizados. En todos los casos se realizaron tres medidas, tomándose la media de las mismas. La Tabla 3 muestra los valores obtenidos en las medidas realizadas sobre las superficies coloreadas utilizando las plantillas negras, la Tabla 4 muestra los valores obtenidos utilizando las plantillas rojas y la Tabla 5, los valores obtenidos utilizando las plantillas amarillas.
4. Colour measurements of the six surfaces characterized in item 3, using templates.

\section{RESULTS}

The results obtained are given in Tables 3, 4 and 5. All values represent the mean of three measurements. The readings taken with black templates are shown in Table 3, with red in Table 4 and yellow in Table 5.

Tabla 3 / Table 3

Medidas de color de los patrones colorimétricos utilizando las plantillas negras Colour measurement of the colourimetric patterns, the black templates being used

\begin{tabular}{|c|c|c|c|c|c|c|c|c|c|c|c|c|}
\cline { 2 - 14 } \multicolumn{1}{c|}{} & \multicolumn{4}{c|}{ N20 } & \multicolumn{4}{c|}{ N30 } & \multicolumn{3}{c|}{ N40 } & \multicolumn{3}{c|}{ N45 } \\
\cline { 2 - 14 } \multicolumn{1}{c|}{} & L* & a* & b* & L* & a* & b* & L* & a* & b* & L* & a* & b* \\
\hline M1 & 38.36 & 21.74 & -0.07 & 45.85 & 33.39 & -0.31 & 52.49 & 43.92 & 1.18 & 56.22 & 48.12 & 0.25 \\
\hline M2 & 49.33 & 1.9 & 7.91 & 61.85 & 3.16 & 11.55 & 72.66 & 4.37 & 15.44 & 78.42 & 4.94 & 16.36 \\
\hline M3 & 36.28 & -4.64 & -16.02 & 42.52 & -7.14 & -25.42 & 48.43 & -9.02 & -30.99 & 50.51 & -9.36 & -35 \\
\hline M4 & 52.26 & -7.52 & 19.36 & 67.97 & -10.81 & 30.47 & 80.41 & -13.28 & 39.85 & 86.02 & -13.94 & 41.87 \\
\hline M5 & 48.63 & -5.52 & -1.28 & 63.14 & -8.16 & -1.38 & 74.59 & -10.41 & -1.44 & 79.43 & -11.6 & -1.47 \\
\hline M6 & 48.87 & -10.73 & 2.89 & 61.02 & -15.12 & 4.51 & 72.26 & -18.48 & 5.18 & 77.97 & -20.38 & 5.83 \\
\hline
\end{tabular}

Tabla 4 / Table 4

Medidas de color de los patrones colorimétricos utilizando las plantillas rojas Colour measurement of the colourimetric patterns, the red templates being used

\begin{tabular}{|c|c|c|c|c|c|c|c|c|c|c|c|c|}
\cline { 2 - 14 } \multicolumn{1}{c|}{} & \multicolumn{3}{|c|}{ R20 } & \multicolumn{3}{c|}{ R30 } & \multicolumn{3}{c|}{ R40 } & \multicolumn{3}{c|}{ R45 } \\
\cline { 2 - 14 } \multicolumn{1}{c|}{} & L* & a* & b* & L* & a* & b* & L* & a* & b* & L* & a* & b* \\
\hline M1 & 55.44 & 53.68 & 13.63 & 56.15 & 53.19 & 9.5 & 57.41 & 52.04 & 4.23 & 57.66 & 52.15 & 3.28 \\
\hline M2 & 62.25 & 38.29 & 17.45 & 69.11 & 25.76 & 17.65 & 75.94 & 14.3 & 17 & 79.21 & 9.22 & 17.98 \\
\hline M3 & 53.42 & 41.11 & 1.06 & 53.2 & 25.79 & -12.87 & 52.4 & 7.41 & -26.85 & 53.08 & -3.22 & -32.25 \\
\hline M4 & 64.65 & 31.47 & 27.03 & 74.15 & 12.8 & 34.31 & 82.88 & -2.46 & 39.57 & 87.21 & -9.74 & 44.26 \\
\hline M5 & 62.14 & 34.22 & 10.26 & 69.51 & 16.97 & 4.86 & 76.75 & 1.47 & 0.83 & 81.06 & -6.97 & -0.88 \\
\hline M6 & 61.19 & 32.38 & 13.62 & 68.26 & 11.5 & 10.27 & 75.06 & -6.64 & 8.29 & 78.49 & -14.93 & 6.66 \\
\hline
\end{tabular}

Los resultados reflejan la relación lineal que existe entre las medidas reales y las obtenidas con plantilla reductora. Esto significa que se puede obtener el valor real de los parámetros $L^{*}$, a* y b* de cualquier superficie, extrapolando a partir de la medida obtenida con una plantilla reductora. La extrapolación se puede realizar por medio de unas sencillas rectas cometiendo un error muy pequeño. En la Tabla 6 se muestran las ecuaciones de las rectas de transformación para las diferentes plantillas reduc-
The results reflect the linear relationship between the measurements taken with and without templates. This means that the real value of parameters $L^{*}, a^{*}$ and $b^{*}$ for any surface can be extrapolated from the measurements taken with a template. Extrapolation may be performed with simple linear plots, subject to only minor error. Table 6 shows the conversion equations for the various templates used, as well as the linear determination coefficient $\left(R^{2}\right)$ values, used as a measure of the pre- 
Tabla 5 / Table 5

Medidas de color de los patrones colorimétricos utilizando las plantillas amarillas

Colour measurement of the colourimetric patterns, the yellow templates being used

\begin{tabular}{|c|c|c|c|c|c|c|c|c|c|c|c|c|}
\cline { 2 - 14 } \multicolumn{1}{c|}{} & \multicolumn{3}{c|}{ A20 } & \multicolumn{3}{c|}{ A30 } & \multicolumn{3}{c|}{ A40 } & \multicolumn{3}{c|}{ A45 } \\
\cline { 2 - 14 } \multicolumn{1}{c|}{} & L* & a* & b* & L* & a* & b* & L* & a* & b* & L* & a* & b* \\
\hline M1 & 84.62 & -0.77 & 37.32 & 76.51 & 13.86 & 25.95 & 67.36 & 31.65 & 14.66 & 63.12 & 40.74 & 7.19 \\
\hline M2 & 89.69 & -8.79 & 39.49 & 86.84 & -3.83 & 31.31 & 84.12 & 1.05 & 24.58 & 83.18 & 3.1 & 20.96 \\
\hline M3 & 84.08 & -13.43 & 28.61 & 73.56 & -12.57 & 6.38 & 64.13 & -11.92 & -14.19 & 58.35 & -11.06 & -25.25 \\
\hline M4 & 92.18 & -14.46 & 47.31 & 91.63 & -14.59 & 46.73 & 91.19 & -15.06 & 47.32 & 90.92 & -14.96 & 45.62 \\
\hline M5 & 90.54 & -13.91 & 35.03 & 87.77 & -13.34 & 20.04 & 85.68 & -12.6 & 8.02 & 84.63 & -12.71 & 3.51 \\
\hline M6 & 89.75 & -16.41 & 37.24 & 86.65 & -18.14 & 27.15 & 83.66 & -20.27 & 15.86 & 82.69 & -21.09 & 10.69 \\
\hline
\end{tabular}

toras utilizadas así como los valores del coeficiente de correlación lineal $\left(R^{2}\right)$ como medida de la exactitud de dichas rectas. Se puede ver que la correlación de los valores reales y los obtenidos reduciendo el área de medida es muy buena (excepto en un caso, $\mathrm{R}^{2}$ es siempre mayor de 0,98$)$. Esto permite utilizar las plantillas antes descritas y transformar los valores de $L^{*}, a^{*}$ y $b^{*}$. cision of the respective linear plots. Note that the correlation between the real values and the readings obtained when the measurement area was reduced was very high ( $R^{2}$ was greater than 0.98 in all but one case). Consequently, the templates described above can be used and the $L^{*}, a^{*}$ and $b^{*}$ values subsequently converted.

Tabla 6 / Table 6

Ecuaciones de las rectas de correlación para las diferentes plantillas y comparación de las desviaciones entre los valores $\left(L^{*}, a^{*}\right.$ y $\left.b^{*}\right)$ reales y los medidos $\left(R^{2}\right)$ Equations of correlation and comparison of the deviations between real values $\left(L^{*}, a^{*}\right.$ and $\left.b^{*}\right)$ and the measured $\left(R^{2}\right)$

\begin{tabular}{|c|c|c|c|}
\hline Plantilla / Template & L* & a* & b* \\
\hline N45 & $\begin{array}{c}1.0770 \times L_{45}-1.8966 \\
R^{2}=1\end{array}$ & $\begin{array}{c}1.0713 \times \mathrm{a}_{45}-0.0530 \\
\mathrm{R}^{2}=1\end{array}$ & $\begin{array}{c}1.0738 \times b_{45}+0.0225 \\
R^{2}=1\end{array}$ \\
\hline R45 & $\begin{array}{c}1.1152 \times L_{45}-6.1396 \\
R^{2}=0.9994\end{array}$ & $\begin{array}{c}1.0894 \times a_{45}-5.1567 \\
R^{2}=0.9993\end{array}$ & $\begin{array}{c}1.0781 \times b_{45}-2.0115 \\
R^{2}=0.9988\end{array}$ \\
\hline A45 & $\begin{array}{c}1.810 \times L_{45}-16.0850 \\
R^{2}=0.9998\end{array}$ & $\begin{array}{c}1.1876 \times a_{45}+2.8195 \\
R^{2}=0.9995\end{array}$ & $\begin{array}{c}1.1638 \times b_{45}-7.1604 \\
R^{2}=0.9987\end{array}$ \\
\hline N40 & $\begin{array}{c}1.1880 \times L_{40}-4.3365 \\
R^{2}=0.9992\end{array}$ & $\begin{array}{c}1.1708 \times a_{40}+0.2250 \\
R^{2}=0.9997\end{array}$ & $\begin{array}{c}1.1655 \times b_{40}-0.6711 \\
R^{2}=0.9997\end{array}$ \\
\hline R40 & $\begin{array}{c}1.2746 \times L_{40}-14.2840 \\
R^{2}=0.9994\end{array}$ & $\begin{array}{c}1.2546 \times \mathrm{a}_{40}-14.1690 \\
\mathrm{R}^{2}=0.9910\end{array}$ & $\begin{array}{c}1.2424 \times b_{40}-3.9132 \\
R^{2}=0.9994\end{array}$ \\
\hline A40 & $\begin{array}{c}1.4187 \times L_{40}-37.5510 \\
R^{2}=0.9981\end{array}$ & $\begin{array}{c}1.4132 \times \mathrm{a}_{40}+6.0516 \\
\mathrm{R}^{2}=0.9980\end{array}$ & $\begin{array}{c}1.3316 \times b_{40}-16.3560 \\
R^{2}=0.9908\end{array}$ \\
\hline N30 & $\begin{array}{c}1.5038 \times L_{30}-10.7750 \\
R^{2}=0.9988\end{array}$ & $\begin{array}{c}1.5153 \times \mathrm{a}_{30}-0.8386 \\
\mathrm{R}^{2}=0.9996\end{array}$ & $\begin{array}{c}1.4764 \times b_{30}+0.2265 \\
R^{2}=0.9995\end{array}$ \\
\hline R30 & $\begin{array}{c}1.8551 \times L_{30}-45.6660 \\
R^{2}=0.9980\end{array}$ & $\begin{array}{c}1.0743 \times \mathrm{a}_{30}-41.8170 \\
\mathrm{R}^{2}=0.9488\end{array}$ & $\begin{array}{c}1.7369 \times b_{30}-13.4400 \\
R^{2}=0.9932\end{array}$ \\
\hline $\mathbf{A 3 0}$ & $\begin{array}{c}2.1819 \times L_{30}-107.8700 \\
R^{2}=0.9983\end{array}$ & $\begin{array}{c}2.2884 \times a_{30}+18.1970 \\
R^{2}=0.9941\end{array}$ & $\begin{array}{c}2.0160 \times b_{30}-47.9350 \\
R^{2}=0.9830\end{array}$ \\
\hline N20 & $\begin{array}{c}2.3453 \times \mathrm{L}_{20}-31.9650 \\
\mathrm{R}^{2}=0.9934\end{array}$ & $\begin{array}{c}2.2850 \times a_{20}+1.4732 \\
R^{2}=0.9987\end{array}$ & $\begin{array}{c}2.3167 \times b_{20}+0.0665 \\
R^{2}=0.9991\end{array}$ \\
\hline $\mathbf{R 2 0}$ & $\begin{array}{c}3.5170 \times \mathrm{L}_{20}-135.4600 \\
\mathrm{R}^{2}=0.9929\end{array}$ & $\begin{array}{c}3.0608 \times a_{20}-118.2600 \\
R^{2}=0.8817\end{array}$ & $\begin{array}{c}3.1429 \times b_{20}-38.4980 \\
R^{2}=0.9870\end{array}$ \\
\hline A20 & $\begin{array}{c}4.4646 \times L_{20}-335.9900 \\
R^{2}=0.9908\end{array}$ & $\begin{array}{c}4.6704 \times a_{20}+52.4090 \\
R^{2}=0.9867\end{array}$ & $\begin{array}{c}4.3847 \times b_{20}-159.4200 \\
R^{2}=0.9806\end{array}$ \\
\hline
\end{tabular}


Si se analizan estas rectas, se pone de manifiesto cómo cada plantilla (color y tamaño de hueco de medida) introduce la misma variación en las tres coordenadas del sistema cromático de la $\mathrm{CIE}$, es decir, las pendientes de las rectas que relacionan los parámetros $L^{*}, a^{*}$ y b* son muy parecidas en cada caso. Esta observación se muestra claramente en la Figura 1.
An analysis of these plots shows that the variation occasioned by each template (colour and size of measurement area) was the same for the three CIE colour coordinates. In other words, the slopes of the lines relating parameters $L^{*}, a^{*}$ and $b^{*}$, respectively, for the two types of measurements, were very similar for each template. This is clearly illustrated in Figure 1.

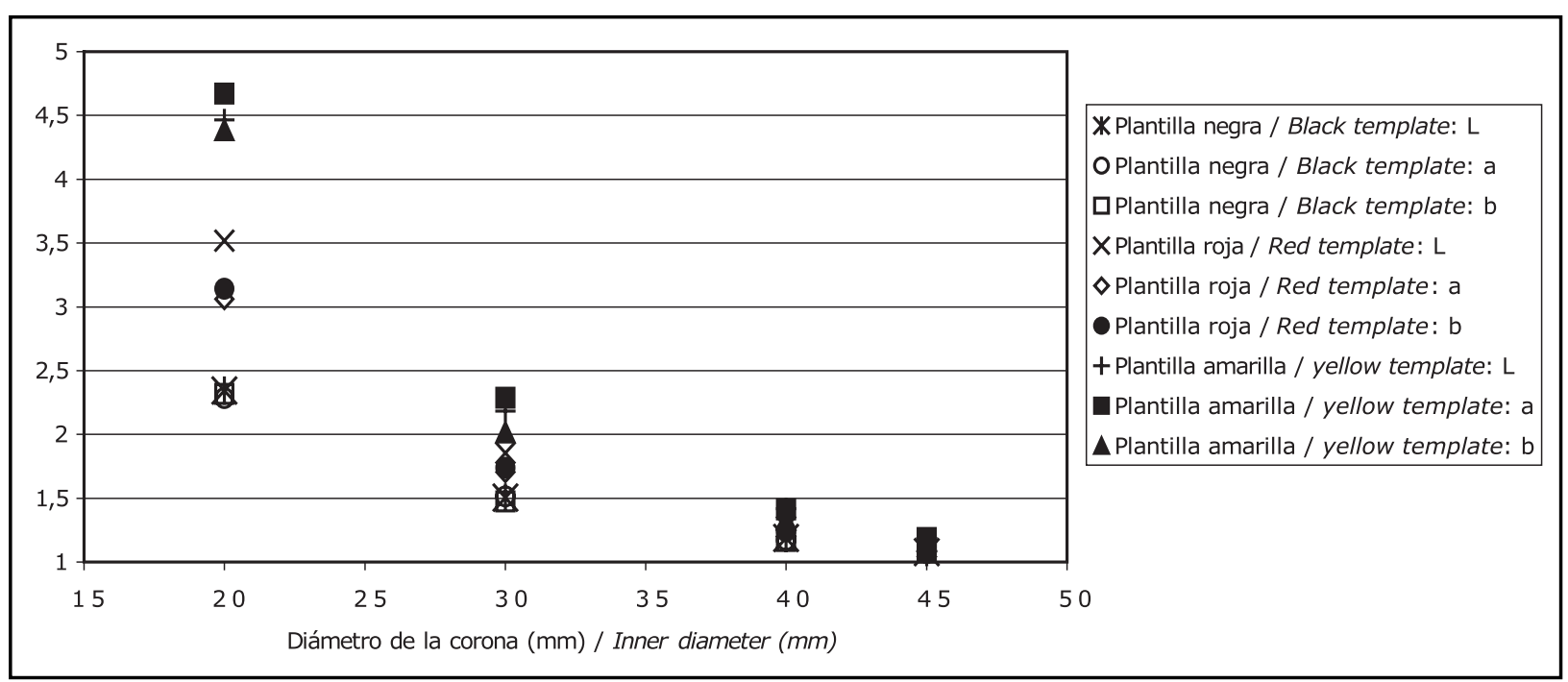

Figura 1. Evolución de las pendientes de las rectas de transformación con el diámetro de hueco de las plantillas.

Figure 1. Evolution of the gradients of the lines of transformation with the hollow diameter of the templates.

Además, en la Figura 1 se puede ver cómo la pendiente de las rectas de transformación disminuye de forma cuadrática con el diámetro interior de las plantillas. Como es lógico, las pendientes tienden al valor 1 (cuando el diámetro interior es igual al diámetro del colorímetro, la medida coincide con la real).

Respecto a los términos independientes de las rectas de correlación, en la Gráfica 2 se ve la dependencia de los mismos con el diámetro de hueco. En el caso de las plantillas negras se muestra claramente la dependencia cuadrática del término independiente de las rectas de transformación de la coordenada $L^{*}$ con el diámetro del hueco de las plantillas. En el caso de las coordenadas $a^{*}$ y b* se puede ver cómo apenas existe dependencia. También se puede comprobar cómo los términos independientes de las tres coordenadas sufren una gran variación con el diámetro de hueco. En el caso de las plantillas rojas, los tres términos independientes tiene dependencia cuadrática con el diámetro del hueco y en el caso de las plantillas amarillas, el término independiente correspondiente a la coordenada a* no sufre apenas variación para las diferentes aperturas estudiadas, mientras que los otros dos, sufren claramente una dependencia cuadrática, igual que en los casos anteriores.
Figure 1 also shows that the slope of the conversion plots declined quadratically as the inner diameter of the templates increased. The slopes logically tended to a value of one (when the inner diameter is equal to the diameter of the colorimeter, the two measurements concur).

The dependence of the independent terms on the inner diameter can be seen in Graph 2. The quadratic dependence of the independent term on the inner diameter of the templates is particularly visible in the $L^{*}$ linear conversion plots for black templates, whereas scarcely any dependence was found for coordinates $a^{*}$ and $b^{*}$. Moreover, the independent terms for the three coordinates varied greatly with the inner diameter. In the red templates, the three independent terms were found to depend quadratically on the inner diameter. In the yellow templates, the independent term for coordinate a* varied scantly at all with the different apertures studied, while the other two parameters exhibited obvious quadratic dependence, as in the preceding cases. 


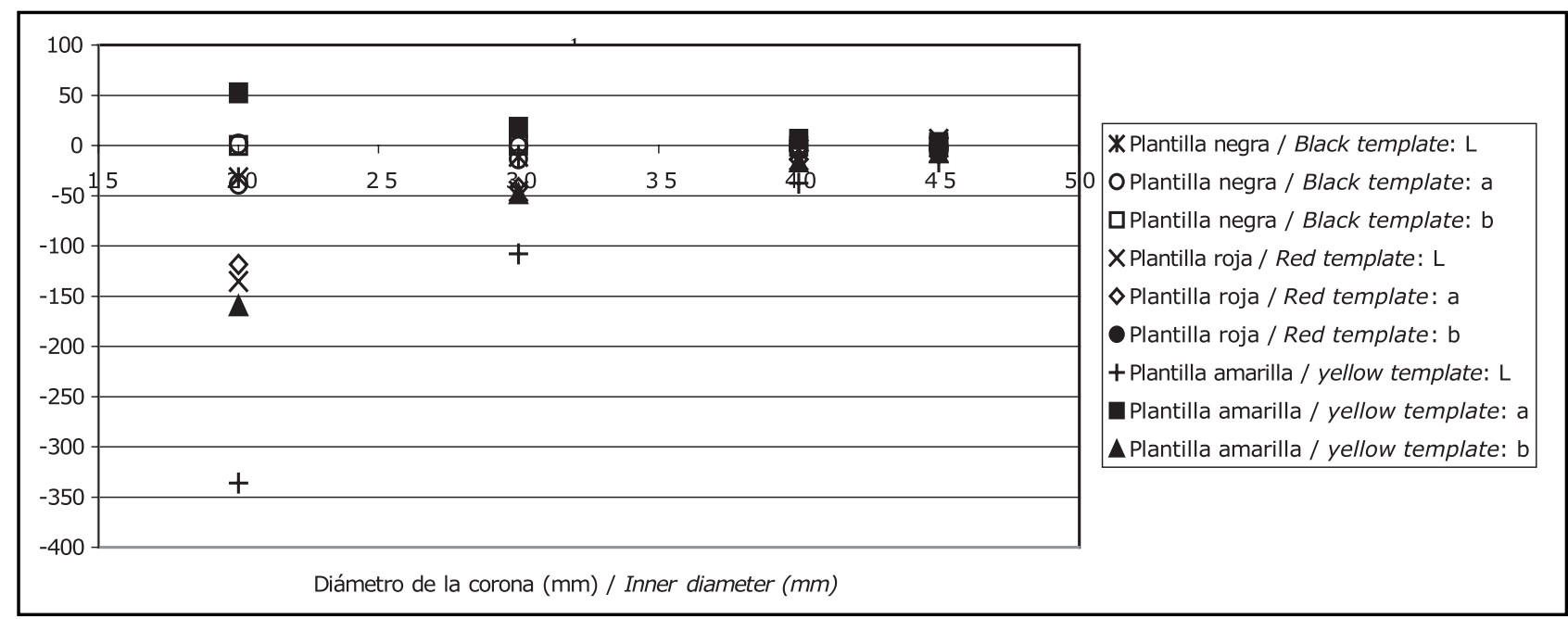

Gráfica 2. Evolución de los términos independientes de las rectas de transformación con el diámetro de hueco de las plantillas. Graph 2. Evolution of the independent terms of the lines of transformation with the templates hollow diameter.

La forma de estas curvas permite predecir las ecuaciones de las rectas de transformación indicando tan sólo el diámetro de hueco de la plantilla seleccionada.

\section{CONCLUSIONES}

Se ha comprobado que la utilización de plantillas para adaptar el tamaño del tubo de proyección a la superficie de medida no sólo es factible, sino que presenta numerosas ventajas. Además, existe una relación lineal entre ambos tipos de medida, y esta relación depende tanto del color como del tamaño del hueco de la plantilla utilizada (ver Tabla 6).

Se observa que las medidas realizadas con una plantilla negra presentan una mejor correlación con las medidas reales que en el caso de utilizar plantillas rojas o amarillas, para cualquier diámetro. Incluso puede verse para el caso de $45 \mathrm{~mm}$ una correspondencia perfecta en los parámetros $\mathbf{a *}$ y b* cuando se utiliza una plantilla negra.

También se pone de manifiesto cómo para cada tipo de plantilla, hay un parámetro con peor comportamiento que los otros dos. Para la plantilla negra, el valor de $\mathbf{L}^{*}$; para la roja, el de a*; y para la amarilla, el de b*, siendo la coordenada $\mathbf{L}^{*}$ la que muestra una menor desviación (ver los valores de $\mathrm{R}^{2}$ en la Tabla 6). Dado que la coordenada $\mathbf{L} *$ representa al negro, la coordenada $\mathbf{a} *$ al rojo, $y$ la b* al amarillo, lo que ocurre es que las plantillas introducen una desviación en la medida de los colores similares al suyo.

Otro punto importante es el tamaño del hueco de las plantillas, ya que al disminuir la apertura de éstas, aumenta el error cometido cuando se usa la correlación.
Hence, when the inner diameter of the template is known, the shape of these curves can be used to predict the equations for the linear conversion plots.

\section{CONCLUSIONS}

The use of templates to adapt the size of the projection tube to the measurement area proved to be not only feasible but advantageous in several ways. Furthermore, the two types of measurements are linearly related, with the relationship depending on both the colour and size of the aperture of the template used (Table 6).

The measurements taken with a black template of whatever diameter were more closely correlated to the real measurements than the readings taken with red or yellow templates. In fact, correlation was found to be perfect for coordinates $\boldsymbol{a}^{*}$ and $\boldsymbol{b}^{*}$ when a black template with a 45$\mathrm{mm}$ aperture was used.

At the same time, in all the templates, the correlation for one of the parameters was consistently poorer than for the other two. For black, it was the $L^{*}$ value; for red, the a* value and for yellow, the $\boldsymbol{b}^{*}$ value, while coordinate $L^{*}$ was the one observed to deviate least (see $R^{2}$ values in Table 6). And coordinate $\boldsymbol{L}^{*}$ happens to represent black, coordinate $\mathbf{a}^{*}$ red and $\boldsymbol{b} *$ yellow. That each colour deviates toward itself would appear to be logical.

Another important factor is the size of the opening in the templates, for as it declined, the error identified by the correlation calculation rose. This is because the smaller 
Esto se debe a que cuánto más pequeña es la zona de medida, más cantidad de color extraño se introduce.

De las observaciones anteriores, se pueden extraer las siguientes conclusiones relativas a las plantillas de reducción de zona de medida del colorímetro:

- Son de fácil diseño y fabricación.

- Para realizar una medida lo más real posible, sería necesario utilizar una plantilla con el mayor área "libre" permitida por la superficie a medir.

- La plantilla ideal es aquélla que esté lo más cerca posible del punto inferior de la esfera de color $\left(L^{*}=0, a^{*}=0\right.$, $\mathrm{b}^{*}=0$ ); $\mathrm{o}$ al menos con $\mathbf{a}^{*}=0$ y $\mathbf{b}^{*}=0$, ya que la coordenada $L^{*}$ es la menos sensible a las desviaciones. Es decir, el color de la plantilla ideal es el negro absoluto.

- Si en la superficie real a medir predomina una o dos coordenadas, será mejor elegir una plantilla con un color sobre el eje de la coordenada no predominante. Es decir, si el de la superficie a medir pertenece al plano L*a*, por ejemplo, lo mejor sería escoger una plantilla amarilla o azul para asegurar que la desviación esté en esta coordenada, y no afecte a la medida que interesa.

- Son adaptables a cualquier tamaño, tanto de tubo de proyección, como de superficie de medida, aunque las ecuaciones de transformación no son universales, son fácilmente calculables siguiendo la metodología que se expone a continuación:

1. Elegir el color de la plantilla que mejor se adapta a la superficie cuyo color se quiere determinar. Esto ocurrirá normalmente con una plantilla negra, excepto en los casos en los que la superficie a medir sea negra, gris o blanca, en cuyo caso la plantilla idónea será de color rojo o amarillo.

2. Seleccionar el diámetro máximo de plantilla que permite la superficie a medir, asegurándose de que el hueco de la plantilla no sea mayor que dicha superficie.

3. Elegir dos muestras de referencia de color.

4. Realizar tres medidas de color sobre cada muestra de referencia, y efectuar la media de los parámetros $L^{*}, a^{*}$ y $b^{*}$ para cada una de ellas.

5. Realizar tres medidas de color sobre cada muestra de referencia utilizando la plantilla seleccionada, y efectuar la media de los parámetros L*, a* y b* para cada una de las muestras. the area measured, the farther removed it is from reality; in other words, the percentage of colour not originating in the specimen tested is higher.

The following conclusions can be drawn from the foregoing:

- Templates that reduce the colorimetric measurement area are easy to design and make.

- To obtain measurements as real as possible, the most suitable template is the one with the largest "open" area compatible with the surface to be measured.

- The ideal template is the one as close as possible to the lowest point on the colour sphere $\left(L^{*}=0 ; a^{*}=0\right.$; $\left.b^{*}=0\right)$, or at least with $\boldsymbol{a}^{*}=0$ and $\boldsymbol{b}^{*}=0$, for coordinate $L^{*}$ is the one least sensitive to deviation. That is to say, black is the ideal colour for a template.

- If one or two coordinates predominate in the actual surface to be measured, the most suitable colour for a template would fall on the non-predominant axis. In other words, if the colour of the surface to be measured is on plane $L^{*} a^{*}$, for instance, a yellow or blue template should be used to ensure that deviation would involve coordinate $b^{*}$ and therefore does not affect the most relevant reading.

- These templates are adaptable to any size of projection tube or measurement area, and although the conversion equations are not universal, they can be readily calculated as described below:

1. Choose the template colour best adapted to the measurement to be taken. Normally, the best choice is a black template except if the surface to be measured is black, grey or white, in which case the best colours are red or yellow.

2. Select the largest diameter compatible with the surface to be measured, ensuring that the opening in the template is not larger than the surface.

3. Choose two reference colour samples.

4. Take three colour readings on each sample and find the mean value for parameters $L^{*}, a^{*}$ and $b^{*}$ for each.

5. Take three colour readings on each sample with the template chosen and find the mean value for parameters $L^{*}, a^{*}$ and $b^{*}$ for each. 
6. Calcular las rectas de transformación para cada uno de los parámetros $L^{*}, a^{*}$ y b*, a partir de los dos puntos ( $L^{*}$ medido con plantillas, $L^{*}$ medido sin plantillas) obtenidos en los apartados 4 y 5.

7. Realizar la medida sobre la superficie a medir utilizando la plantilla, y transformar el valor de cada parámetro $\left(L^{*}, a^{*}\right.$ y $\left.b^{*}\right)$ utilizando las ecuaciones calculadas en el apartado 6 .
6. Find the conversion graphs for parameters $L^{*}, a^{*}$ and $b^{*}$ from the two points ( $L^{*}$ measured with templater $L^{*}$ measured without template) obtained in items 4 and 5 .

7. Take the reading on the surface to be measured with the template and convert the value for each parameter $\left(L^{*}, a^{*}\right.$ and $\left.b^{*}\right)$ using the equations found in item 6 .

\section{BIBLIOGRAFÍA / BIBLIOGRAPHY}

(1) Tantaswadi, P.: "Applications of colorimetry in machine visions for checking electronic components and quality of pulp paper". Proceedings of SPIE - The International Society for Optical Engineering, vol. 4535 (2000), pp. 119-125.

(2) Bruecker, F.: "Zur theorie und praxis der farbmessung als massnahme der qualitaetssicherung an keramikoberflaechen (colorimetry in theory and practice as a quality assurance measure for ceramic surfaces)". CFI, Ceramic Forum-Int/Berichte der DKG (Deutschen Keramischen Gesellschaft), vol. 58, no 3 (1981), pp. 180-184.

(3) Chao, M. K., Hake, B. P.: "Colorimetry applications in the automotive industry". Proceedings of SPIE - The International Society for Optical Engineering, vol. 411 (1983), pp. 47-48.

(4) Kopec, G. J.: "Colorimetry as diagnostic tool in manufacture of antireflection coatings". Proceedings of SPIE - The International Society for Optical Engineering, vol. 4517 (2001), pp. 236-241.

(5) Mangine, H. Jakes, K., Noel, C.: "A preliminary comparison of CIE color differences to textile color acceptability using average observers". Color Research and Application, vol. 30, no 4 (2005), pp. 288-294. http://dx.doi.org/10.1002/col.20124

(6) Alcalde, M., Villegas, R. Vale, J. F., Martín, A.: Diagnosis y tratamiento de la piedra. I. La alteración de la piedra en los monumentos.

II. Consolidantes e hidrófugos. Productos para el tratamiento de materiales pétreos. Madrid, C.S.I.C. 1990.

(7) Villegas, R., Espinosa, J.: "La investigación científica aplicada a la caracterización de materiales y la selección de tratamientos de conservación". Ph. Boletín del Instituto andaluz del patrimonio histórico vol. 8, no 33 (2000).

(8) Villegas, R.: "Evaluation of Treatment Products for the Front Door of the Church of Santiago, Guadix". Mater. Construcc., vol. 51, no 261 (2001), pp. 21-32.

(9) D 'Ossat, A.: Guide to the methodical study of monuments and causes of their deterioration. Faculty of architecture of Rome. ICCROM. 1982.

(10) Alejandre, F. J., Villegas, R.; Jurado, M.: "Evaluation of Performance of Materials Used in the Ceramic Materials of the Plaza de España (Sevilla)". Mater. Construcc., vol. 55, no 278 (2005), pp. 69-76.

(11) Grossi, C. M., Brimblecombe, P.: "Past and future colouring patterns of historic stone buildings". Mater. Construcc., vol. 58, no 289290 (2008), pp. 143-160.

(12) Prieto, B., Silva, B.: "Biofilm quantification on stone surfaces: comparison of various methods". Science of the Total Environment, 333 (2004), pp. 1-7. http://dx.doi.org/10.1016/j.scitotenv.2004.05.003

(13) Prieto, B., Rivas, T., Silva, B.: "Rapid quantification of photographic microorganisms and their physicological state through their colour". Biofouling, vol. 18, no 3 (2002), pp. 229-236.

(14) Mellégol, J., Lemaire, J., Gardette, J. L.: "Yellowing of oil-based paints". Studies in Conservation, vol. 46, no 2 (2001), pp $121-131$. http://dx.doi.org/10.2307/1506842

(15) Koestler, R. J., Parreira, E., Santoro, E. D., Noble, P.: "Visual effects of selected biocides on easel painting materials". Studies in Conservation, vol. 38, no 4 (1993), pp. 165-173.

(16) Varas, M. J., Molina, E., Vicente, M. A.: "Areniscas ornamentales empeladas en Ciudad Rodrigo, Salamanca: caracterización petrográfica y química de los materiales de cantera". Mater. Construcc., vol. 52, nº 266 (2002).

(17) Artigas, J. M., Pujol i Ramo, J., Capilla Perea, P.: "Fundamentos de colorimetría" (ISBN: 8437054206).

(18) CIE (Comission International de I'Eclaraige). Recommendations on uniform color spaces, color difference equations psychometric color terms. Supplement $n^{\circ} 2$ to CIE publication no 15. Colorimetry. Bureau central de la CIE. (1976). 